\title{
Tropical soils and agrotechnology transfer
}

\author{
from Ian Smalley
}

MORE food needs to be produced in the third world, in the countries which are grouped in the tropical regions. But the soils of the tropics often have a 'variable charge' character which makes them sufficiently different from most soils of the temperate regions that research in the developed world can not be directly applied. The transfer of agriculture technology between the developed and the developing world can thus encounter fundamental problems.

Various aspects of variable charge soils, and in particular the problems of classification and of transfer of agricultural technology, were discussed at a recent meeting* at Massey University in New Zealand. In variable charge soils the electrical charge on the particle surfaces, both in magnitude and sign, can vary greatly with changes in the $p \mathrm{H}$, ionic strength and composition of the soil solutions. The variable charge nature of the soils arises from the abundance, in the clay fraction, of minerals having amphoteric (positive or negative) surfaces. Prominent among such minerals are the oxides and hydrous oxides of aluminium and iron which may be crystalline, paracrystalline or poorly ordered. The 1:1 type layer silicates, such as halloysite and kaolinite, also show amphoteric properties, associated with their relatively large exposed crystal edge surface. On the other hand, the negative surface charge of 2:1 clay minerals arises from extensive isomorphous substitution within the structure and hence is largely independent of $p \mathrm{H}$. Thus soils rich in micaceous and similar minerals are said to be of constant or permanent charge.

Besides having amphoteric surfaces, clay-size minteral constituents with variable charge generally have a low capacity to adsorb or retain nutrient cations in the range of $p \mathrm{H}$ and ionic conditions which prevail in natural soil systems. For this reason, these constituents have been grouped together and referred to as 'low activity clays'. Thus, soils rich in low activity clays are, in general, naturally infertile and this causes a major problem in tropical agriculture. Although the amphoteric nature of some soils and soil constituents has been recognised for a long time, it is only relatively recently that its importance, in terms of soil processes and management, has come to be appreciated. This is because soil research, as carried out in the developed countries of Europe and North America, has largely been directed to understanding the behaviour of temperate soils, many of which are of the

*'Soils with Variable Charge' Conference: Commissions 4-7 of the International Society of Soil Science; $11-18$ February, 1981. Conference Book (ed. B.K.G. Theng) publ. NZ Soc. Soil Sci. constant charge type. The variable charge constituents, if they were not altogether ignored, were often regarded as contaminants and removed from the system.

A common constituent of volcanic variable-charge soils is the clay mineral allophane (now widely believed to have a spherical structure: see News \& Views, Nature, 281, 339, 1979). Recent studies on allophane in New Zealand soils were reported by R. Parfitt (NZ Soil Bureau). Allophane has been defined as a series of naturally occurring hydrous aluminosilicate clays, characterised by short range order and by the predominance of Si-O-Al bonds, and it appears to be made up of hollow spherules $3.5-5.0 \mathrm{~nm}$ in diameter. Spherules with a molar ratio close to $\mathrm{Al} / \mathrm{Si}=2.0$ from $\mathrm{Mt}$ Egmont andesitic pumice have the proto-imogolite infrared spectrum. This, together with X-ray fluorescence, pyridine adsorption and silicate analysis data, indicate that the wall of the allophane spherule is made up of imogolite segments. The fine tubular crystals of imogolite are also found in New Zealand soils.

Allophane $(\mathrm{Al} / \mathrm{Si}=2.0)$ occurs in several different environments in New Zealand. It is the dominant clay mineral in an Egmon soil formed from andesitic ash, in a Taupo soil formed from rhyolitic Taupo pumice, and in a Mairoa soil formed from rhyolitic ash. In rhyolitic ash, allophane $(\mathrm{Al} / \mathrm{Si}=2.0)$ is the dominant clay mineral where the annual rainfall exceeds about $1,600 \mathrm{~mm}$. Where the annual rainfall is less than $1,600 \mathrm{~mm}$, allophane and halloysite are the dominant clay minerals, with allophane decreasing and halloysite increasing in older tephras. Halloysite is the dominant clay mineral in a Kereone soil, where the rainfall is $1,200 \mathrm{~mm}$.

Allophane soils present a problem for mechanical analysis and clay recovery because at field $p \mathrm{H}$ or in acid media the positively charged allophane flocculates with any crystalline clay present by charge interaction, and in alkali or calgon solution it is self-flocculating by some unknown mechanism. Studies of Scottish allophanic subsoils by H.J. Fullerton (University of Glasgow) showed that these behave like New Zealand allophane soils in that they flocculate by charge interaction when vibrated in water and continue to flocculate at all alkali $p \mathrm{H}$ values. Unlike allophane soils, however, they deflocculate in calgon solution. Alkaline flocculation appears to be not a rare property confined to allophane, but a common property of disordered clay surfaces.

The major technology transfer project discussed, the Benchmark Soils Project, is being applied to three soil types across the tropical world. Three different soil families have been chosen for experimentation: the clayey, kaolinitic, isohyperthermic Tropeptic Eutrustox (the terminology of the USDA-developed 'soil taxonomy' system is used); the thixotropic, isothermic Hydric Dystrandepts; and clayey, kaolinitic, isohyperthermic Typic Paleudults. These soil families represent three different agroclimatic zones: dry and warm (the Eutrustox), moist and cool (the Dystrandepts), and moist and warm (the Paleudults). The soils all have distinct variable charges which influence soil management and utilization. G. Uehara (University of Hawaii) reported that technology transfer in 15 separate areas was being attempted; among these were selection of tree crops for windbreak, fuelwood and erosion control, susceptibility of salinization, and soil workability and trafficability.

The Benchmark Soils Project comprises two companion research contracts awarded to the Universities of Hawaii and Puerto Rico in 1974 and 1975 by the US Agency for International Development. The primary objective of the project is to test the hypothesis that agro-production technology, particularly soil management experience, can be transferred among tropical countries on the basis of soil families as defined in the system of soil taxonomy. The project has established a research network that includes 23 experimental sites in Brazil, Cameroon, Hawaii, Indonesia, the Philippines and Puerto Rico. The basic research strategy is to select soils belonging to the same soil families in widely separated geographical areas, subject these soils to identical and standardized experiments, and correlate the plant yields. The transfer experiments are complemented by pragmatic management experiments and variety trials intended to expand the basic knowledge of crop production for each soil family.

R.L. Fox (University of Hawaii) pointed out that in their attempts to replace the humus theory of plant nutrition with the inorganic nutrient theory, early naturalists assumed that it was only necessary to replace the nutrients removed in the harvest. Phosphate reversion, $\mathrm{K}$ fixation, denitrification, soil erosion and leaching of nutrients were not sufficiently recognized. We now know that a soil fertility programme that is content with returning nutrients exported in the harvest is not sufficient at all. This fundamental mistake has been repeated almost endlessly during the past century - most recently in the tropics. Nowhere are the consequences likely to be so acute as on the weathered, variable charge soils which are abundant there.

Ian Smalley is with the New Zealand Soil Bureau, Lower Hutt, New Zealand. 